\title{
PENGARUH PENDEKATAN SAINTIFIK BERMEDIAKAN AUDIO VISUAL TERHADAP KETERAMPILAN MENULIS PADA MUATAN PELAJARAN BAHASA INDONESIA
}

\author{
Ni Putu Artini \\ Jurusan Pendidikan Guru Sekolah Dasar, FIP \\ Universitas Pendidikan Ganesha \\ Singaraja, Indonesia \\ e-mail: artini1448@gmail.com
}

\begin{abstract}
Abstrak
Penelitian ini bertujuan untuk mengetahui pengaruh yang signifikan pendekatan saintifik bermediakan audio visual terhadap keterampilan menulis pada muatan pelajaran bahasa Indonesia siswa kelas IV SD Gugus XIV Kecamatan Buleleng Kabupaten Buleleng tahun pelajaran 2017/2018. Penelitian ini tergolong jenis penelitian eksperimen semu. Populasi penelitian ini adalah seluruh siswa kelas IV SD Gugus XIV Kecamatan Buleleng Kabupaten Buleleng tahun pelajaran 2017/2018 yang berjumlah 5 kelas. Sampel penelitian ditentukan menggunakan teknik random sampling. Sekolah yang menjadi sampel yaitu SDN 1 Pemaron sebagai kelompok eksperimen dan SDN 1 Tukadmungga sebagai kelompok kontrol. Data keterampilan menulis dikumpulkan menggunakan tes unjuk kerja kemudian dianalisis menggunakan teknik analisis statistik deskriptif dan statistik inferensial (uji-t). Berdasarkan hasil analisis data, diperoleh $t_{\text {hitung }}=7,32$ dan $t_{\text {tabel }}$ (taraf signifikansi $5 \%$ ) $=2,006$. Hal ini berarti bahwa $t_{\text {hitung }}>t_{\text {tabel }}$ sehingga terdapat perbedaan yang signifikan pendekatan saintifik bermediakan audio visual terhadap keterampilan menulis pada muatan pelajaran bahasa Indonesia. Di samping itu, didapatkan pula bahwa mean kelompok ekperimen adalah 20,14 dan mean kelompok kontrol adalah 14,8. Dengan demikian, dapat disimpulkan bahwa pendekatan saintifik bermediakan audio visual berpengaruh signifikan terhadap keterampilan menulis bahasa Indonesia siswa kelas IV SD Gugus XIV Kecamatan Buleleng Kabupaten Buleleng Tahun Pelajaran 2017/2018. Disarankan kepada pihak sekolah untuk mewajibkan media audio visual sebagai salah satu media pembelajaran yang harus diterapkan dalam pembelajaran sehingga pembelajaran yang dilakukan menjadi menarik dan dapat meningkatkan hasil belajar siswa.
\end{abstract}

Kata kunci: Audio Visual, Keterampilan Menulis, Saintifik

\begin{abstract}
This study is purpose to know the effect of scientific approach which using audio visual method towards students' writing skill in Bahasa subject grade IV of SD in cluster XIV Buleleng sub district, Buleleng regency in academic year 2017/2018. This study is quasi experiment. The populations of this study were all the students in IV grade of SD in cluster XIV Buleleng sub district, Buleleng regency in academic year 2017/2018 which the total classes were 5 classes. The sample of this study determined using random sampling theory. The sample was SDN 1 Pemaron were 28 students as experiment group and SDN 1 Tukadmungga were 27 students as control group. The writing skill' data was collected using test for the task then analyzed using descriptive statistics analysis technique and inferential (uji-t). Based on the result of analysis data the result was $t_{\text {observed }}=7,32$ and $t_{\text {critical value }}$ (significance level $5 \%)=2,006$. The result showed that $t_{\text {observed }}>t_{\text {critical value }}$ then it could be seen the significance difference about the scientific aproach which using audio visual media towards students' writing skill on Bahasa subject. Besides that in this study could be found that mean of experiement group was 20,14 and mean of control group was 14,8. It can be concluded that scientific approach which using audio visual media has significance effect towards students' wiring skill in Bahasa subject in grade IV of SD cluster XIV Buleleng sub district, Buleleng regency in academic year 2017/2018. It suggested for the school is a must using audio visual media in teaching learning process to make the students and the learning process will be interesting and can be raise students learning result.
\end{abstract}

Keywords: Audio Visual, Writing Skill, Scientific

Jurnal IImiah Pendidikan Profesi Guru | 91 


\section{Pendahuluan}

Pembelajaran bahasa Indonesia diarahkan untuk meningkatkan kemampuan peserta didik agar mampu berkomunikasi dengan baik dan benar serta melatih kemampuan berpikir kritis dan kreatif. Yunus (2014:31) menyatakan "pembelajaran bahasa Indonesia merupakan pembelajaran yang bertujuan untuk mengasah dan membekali mereka dengan kemampuan berkomunikasi atau kemampuan menerapkan bahasa Indonesia dengan tepat untuk berbagai tujuan dan dalam konteks yang berbeda". Pembelajaran bahasa juga mengarah pada proses perolehan keterampilan berbahasa. Susanto (2013:242) menyatakan "pembelajaran bahasa Indonesia tidak terlepas dari empat keterampilan berbahasa yaitu menyimak, berbicara, membaca dan menulis". Keempat keterampilan berbahasa ini merupakan keterampilan yang wajib dimiliki peserta didik sebagai modal awal untuk berinteraksi dengan orang lain. Agar siswa dapat menggunakan bahasa dalam suatu interaksi, maka ia harus memiliki keterampilan berbahasa. Keterampilan itu digunakan untuk mengomunikasikan suatu pesan. Pesan ini dapat berupa ide, gagasan, perasaan, keinginan dan interaksi. Salah satu cara yang bisa digunakan untuk berinteraksi adalah melalui menulis. Menurut Wicaksono (2017) Bahasa Indonesia merupakan salah satu mata pelajaran penting di Indonesia. Hal ini terbukti dari sekian banyak mata pelajaran yang diajarkan, Bahasa Indonesia menjadi salah satu materi Ujian Nasional (UN) pada berbagai jenjang pendidikan dasar dan menengah. Hanya saja, kenyataan ini tidak diikuti dengan keseriusan dari pemangku kepentingan dalam memperbaiki permasalahan yang terjadi di lapangan.

Menulis sebagai keterampilan seseorang (individu) mengomunikasikan pesan dalam sebuah tulisan. Keterampilan ini berkaitan dengan kegiatan seseorang memilih, memilah dan menyusun pesan untuk disampaikan melalui bahasa tulis. Sumantri, dkk. (2014:104) menyatakan "keterampilan menulis adalah keterampilan menuangkan ide, gagasan, dan perasaan dalam bentuk bahasa tulis sehingga orang lain yang membaca dapat memahami isi tulisan dengan baik". Melalui sebuah tulisan, pembaca dapat memahami pesan yang disampaikan serta tujuan penulisan. Keterampilan menulis tidak bisa dikuasai dalam waktu singkat, diperlukan latihan dan praktik yang tidak sedikit dan terus menerus. Melalui kegiatan menulis siswa dapat melatih kemampuan mengorganisasikan dan menjernihkan berbagai ide atau gagasan, dapat memunculkan ide baru, menyerap dan memperoleh informasi serta membantu untuk berpikir aktif. Berdasarkan pernyataan tersebut, dapat dipertegas bahwa keterampilan menulis adalah salah satu dari empat keterampilan berbahasa yang mempunyai peran penting untuk mengungkapkan pikiran atau gagasan agar mencapai maksud dan tujuan yang ingin disampaikan dalam kehidupan manusia.

Berhasilnya suatu proses pembelajaran menulis tidak terlepas dari usaha seorang guru dalam menarik minat siswa untuk belajar. Diperlukan variasi pembelajaran yang memungkinkan siswa dapat mencari, menemukan, menggali dan menyampaikan ide-ide dalam menulis. Pelaksanaan pembelajaran berdasarkan kurikulum 2013 yaitu menggunakan pendekatan saintifik atau pendekatan berbasis keilmuan. Musfiqon dan Nurdyansyah (2015:57) menyatakan "penerapan pendekatan saintifik dalam pembelajaran di sekolah bertujuan untuk membiasakan peserta didik berpikir, bersikap serta berkarya dengan menggunakan kaidah dan langkah ilmiah. Pendekatan saintifik meliputi lima langkah belajar yaitu mengamati, menanya, mencoba, mengasosiasi dan mengomunikasikan". Kelima langkah ini sesuai diterapkan pada pembelajaran menulis karena dapat melatih siswa dalam kegiatan menulis, mulai dari mencari ide topik yang akan ditulis, mengolah ide tersebut sampai mengomunikasikan tulisannya. Hal ini akan membuat siswa memiliki kemampuan menulis yang baik.

Namun kenyataannya, berdasarkan hasil wawancara yang dilakukan dengan guru kelas IV SD Gugus XIV Kecamatan Buleleng, didapatkan hasil bahwa dalam pembelajaran menulis guru mengalami beberapa kesulitan. Kesulitan tersebut diantaranya yaitu sulit untuk membuat siswa tertarik untuk mengikuti pembelajaran menulis, kurangnya pemahaman 
dalam menggunakan media maupun model pembelajaran dan sulit membuat siswa terlibat aktif saat pembelajaran.

Hal ini didukung dengan hasil observasi yang dilakukan di kelas selama pembelajaran menulis. Hasilnya ditemukan sebagai berikut. 1) guru mengajar tidak menggunakan model maupun media pembelajaran, 2) siswa tampak tidak tertarik mengikuti pembeajaran, 3) siswa kesulitan menemukan ide topik yang akan ditulis, dan 4) siswa kebingungan dan kurang percaya diri dalam mengembangkan ide yang telah didapat. Berdasarkan hasil yang diperoleh saat observasi, dapat disimpulkan bahwa pembelajaran yang dilakukan oleh guru tidak menarik minat siswa untuk belajar sehingga siswa menjadi kurang aktif saat pembelajaran.

Pernyataan tersebut diperkuat dengan pencatatan dokumen berupa rata-rata keterampilan menulis siswa yang diperoleh dari guru kelas IV SD Gugus XIV Kecamatan Buleleng yang dijabarkan pada Tabel 1.

Tabel 1. Rata-rata Keterampilan Menulis Bahasa Indonesia SD

\begin{tabular}{lcc}
\hline $\begin{array}{c}\text { SD Gugus XIV Kecamatan } \\
\text { Buleleng }\end{array}$ & $\begin{array}{c}\text { KKM Bahasa } \\
\text { Indonesia }\end{array}$ & $\begin{array}{c}\text { Rata-rata Nilai Keterampilan } \\
\text { Menulis }\end{array}$ \\
\hline SDN 1 Pemaron & 70 & 67,96 \\
SDN 2 Pemaron & 70 & 69,92 \\
SDN 1 Tukadmungga & 70 & 68,96 \\
SDN 2 Tukadmungga & 70 & 69,06 \\
SDN 3 Tukadmungga & 67 & 66,72 \\
\hline
\end{tabular}

Berdasarkan data pada Tabel 1, diketahui terdapat kesenjangan antara harapan dan kenyataan pada muatan pelajaran bahasa Indonesia khususnya keterampilan menulis. Hasil pada tabel tersebut terlihat bahwa keberhasilan pencapaian nilai keterampilan menulis pada muatan pelajaran Bahasa Indonesia kelas IV SD Gugus XIV Kecamatan Buleleng tergolong rendah dan belum mencapai hasil belajar yang memuaskan. Hal ini dapat terlihat dari nilai rata-rata keterampilan menulis siswa yang masih di bawah KKM.

Berdasarkan permasalahan tersebut, pelu diadakan pembelajaran yang dapat membuat siswa aktif dan senang belajar menulis. Menurut Sayidiman (2012) Penerapan strategi pembelajaran yang kurang tepat dapat mengakibatkan kualitas pembelajaran tidak dapat tercapai sebagaimana yang direncanakan. Media pembelajaran merupakan langkah strategis yang dapat ditempuh dalam rangka meningkatkan minat mahasiswa terhadap mata kuliah tertentu terutama mata kuliah yang mengedepankan aspek psikomotor yang memerlukan peragaan peragaan dan demonstrasi serta contoh-contoh konkrit sebagaimana yang tertuan dalam konsep pembelajaran. Guru dalam pembelajaran seharusnya dapat menciptakan pembelajaran yang inovatif sesuai kebutuhan siswa khususnya dalam meningkatkan keterampilan menulis. Guna memenuhi hal tersebut, pembelajaran yang dipilih dan sesuai untuk mengatasi masalah yang terjadi adalah pembelajaran yang difokuskan untuk menarik minat siswa dalam mengikuti pembelajaran menulis. Salah satu yang dapat dilakukan oleh guru yaitu memilih media pembelajaran yang tepat. Media merupakan saluran pesan dari sumber pesan kepada peserta didik. Tegeh, (2010:7) menyatakan "media merupakan sesuatu yang bersifat meyakinkan pesan dan dapat merangsang pikiran, perasaan, dan kemauan audiens atau siswa sehingga dapat mendorong terjadinya proses belajar pada diri siswa tersebut". Dengan menggunakan media pembelajaran, siswa akan termotivasi untuk belajar dan pembelajaran menjadi bermakna.

Media pembelajaran yang dapat memotivasi siswa dalam mengikuti pembelajaran menulis adalah media audio visual. Menurut Supriatini (2017) media audio visual merupakan media perantara atau penggunaan materi dan penyerapannya melalui pandangan dan pendengaran sehingga membangun kondisi yang dapat membuat siswa mampu memperoleh pengetahuan, keterampilan, atau sikap. Contohnya; televisi, slide bersuara, 
film, video, dan lain sebagainya. Menurut Hasan (2016) Media audio visual merupakan salah satu sarana yang tepat dalam proses belajar mengajar. Dalam kenyataannya banyak guru yang tidak menggunakan media audio visual dalam proses pembelajaran. Djamarah dan Zain (2006:124) menyatakan "media audio visual adalah media yang mempunyai unsur suara dan unsur gambar. Jenis media ini mempunyai kemampuan yang lebih baik, karena meliputi kedua jenis media yaitu audio dan visual. Alat-alat yang termasuk dalam kategori media audio visual adalah televisi, video atau VCD, serta sound dan film". Dengan menggunakan media audio visual, siswa memanfaatkan dua indera sekaligus yaitu indera pendengaran dan indera penglihatan yang dapat membuat suasana belajar menjadi lebih menarik. Dan yang terpenting dapat memperjelas materi yang ingin disampaikan guru kepada siswa. Penggunaan media audio visual akan dipadukan dalam pendekatan saintifik sehingga pembelajaran menulis yang dilakukan oleh siswa menjadi bermakna dan menyenangkan.

Berdasarkan pemaparan di atas, pembelajaran dengan pendekatan saintifik bermediakan audio visual perlu diterapkan. Untuk itu, diangkat masalah ini melalui penelitian yang berjudul "Pengaruh Pendekatan Saintifik Bermediakan Audio Visual Terhadap Keterampilan Menulis pada Muatan Pelajaran Bahasa Indonesia Siswa Kelas IV SD Gugus XIV Kecamatan Buleleng Kabupaten Buleleng Tahun Pelajaran 2017/2018".

Berdasarkan uraian tersebut, penelitian ini bertujuan untuk mengetahui pengaruh yang signifikan pendekatan saintifik bermediakan audio visual terhadap keterampilan menulis pada muatan pelajaran bahasa Indonesia siswa kelas IV SD Gugus XIV Kecamatan Buleleng Kabupaten Buleleng Tahun Pelajaran 2017/2018.

\section{Metode}

Penelitian ini dilaksanakan di SD Gugus XIV Kecamatan Buleleng. Penelitian ini dirancang pada kelas IV semester genap tahun pealajaran 2017/2018. Jenis penelitian ini merupakan penelitian eksperimen semu. Desain penelitian ini yaitu Non Equivalent PostTest Only Control Group Design. Desain ini dapat dilihat pada Tabel 2.

Tabel 2. Desain Penelitian

\begin{tabular}{lll}
\hline Kelompok & Perlakuan & Post-test \\
\hline Eksperimen & $\mathrm{X} 1$ & O1 \\
Kontrol & - & O2 \\
\hline
\end{tabular}

Keterangan:

X1 : perlakuan kelompok eksperimen

- : perlakuan kelompok kontrol

O1 : post-test kelompok eksperimen

$\mathrm{O} 2$ : pos- test kelompok kontrol

Populasi penelitian ini adalah seluruh siswa kelas IV SD Gugus XIV Kecamatan Buleleng Tahun Pelajaran 2017/2018 yang berjumlah 114 siswa. Distribusi populasi penelitian ini dapat dilihat pada tabel 3.

Tabel 3. Distribusi Populasi Penelitian

\begin{tabular}{ccc}
\hline No. & Sekolah & Jumlah Siswa \\
\hline 1 & SDN 1 Pemaron & 28 \\
2 & SDN 2 Pemaron & 24 \\
3 & SDN 1 Tukadmungga & 27 \\
4 & SDN 2 Tukadmungga & 17
\end{tabular}


Sebelum menentukan sampel, terlebih dahulu dilakukan uji kesetaraan populasi. Uji kesetaraan populasi dilakukan dengan menganalisis nilai ketarampilan menulis pada muatan pelajaran bahasa Indonesia menggunakan uji anava satu jalur. Berdasarkan hasil analisis pada taraf signifikansi $5 \%$, diperoleh nilai $\mathrm{F}_{\text {hitung }}=0,00183$, sedangkan $\mathrm{F}_{\text {tabel }}$ pada $\mathrm{db}_{\mathrm{antar}}=4$ dan $\mathrm{db}_{\text {dalam }}=109$ adalah 2,45. Dengan demikian, terlihat nilai $F_{\text {hitung }}<F_{\text {tabel }}(0,00183<2,45)$, sehingga $\mathrm{H} 0$ diterima dan $\mathrm{H} 1$ ditolak. Jadi, terdapat perbedaan yang signifikan keterampilan menulis bahasa Indonesia siswa kelas IV SDN Gugus XIV Kecamatan Buleleng Tahun Pelajaran 2017/2018. Dengan kata lain, kemampuan menulis siswa kelas IV SD Gugus XIV Kecamatan Buleleng tahun Pelajaran 2017/2018 adalah setara.

Sampel penelitian ini diambil menggunakan teknik random sampling karena semua populasi setara. Dari hasil random, dua sekolah yang muncul yaitu SDN 1 Pemaron dan SDN 1 Tukadmungga. Untuk menentukan kelompok eksperimen dan kelompok kontrol, sampel diundi kembali. Dari hasil pengundian yang muncul yaitu SDN 1 Pemaron yang berjumlah 28 orang sebagai kelompok eksperimen dan SDN 1 Tukadmungga yang berjumlah 27 orang sebagai kelompok kontrol. Kelompok eksperimen diberikan perlakuan dengan menerapkan pendekatan saintifik bermediakan audio visual, sedangkan kelompok kontrol tidak diberikan perlakuan.

Variabel dalam penelitian ini ada dua yaitu variabel bebas dan variabel terikat. Variabel bebas pada penelitian ini adalah pendektan saintifik bermediakan audio visual, sedangkan variabel terikat pada penelitian ini adalah keterampilan menulis pada muatan pelajaran bahasa Indonesia. Data yang dikumpulkan dalam penelitian ini adalah data keterampilan menulis bahasa Indonesia siswa kelas IV. Instrumen yang digunakan adalah tes unjuk kerja yang berjumlah 1 soal. Sebelum tes digunakan, terlebih dahulu instrumen diujicobakan untuk mengetahui validitas dan reliabilitas soal. Teknik analisis data yang digunakan adalah analisis statistik deskriptif dan analisis inferensial (uji-t). Sebelum menguji hipotesis dengan uji-t, terlebih dahulu data diuji normalitas menggunakan rumus Chi-Kuadrat dan homogenitas varians menggunakan uji F.

\section{Hasil dan Pembahasan}

Deskripsi data hasil penelitian meliputi (1) deskripsi data hasil post-test kelompok eksperimen dan (2) deskripsi data hasil post-test kelompok kontrol. Rekapitulasi hasil penghitungan data hasil post-test disajikan pada Tabel 4.

Tabel 4. Hasil Penghitungan Data Post-Test

\begin{tabular}{lcc}
\hline \multicolumn{1}{c}{ Statistik } & Kelompok Eksperimen & Kelompok Kontrol \\
\hline Mean & 20,14 & 14,80 \\
Median & 20,70 & 15 \\
Modus & 21,30 & 16,30 \\
Varians & 7,12 & 7,92 \\
Standar Deviasi & 2,68 & 2,81 \\
Skor Maksimal & 24 & 18 \\
Skor Minimal & 13 & 8 \\
\hline
\end{tabular}

Berdasarkan Tabel 4, diketahui kelompok ekperimen memiliki skor rata-rata keterampilan menulis yaitu 20,14. Skor rata-rata keterampilan menulis kelompok ekperimen berada pada kategori sangat tinggi setelah dikonversikan ke dalam PAP skala lima. Data kelompok ekperimen pada tabel 4 disajikan dalam bentuk kurva poligon pada gambar 1 . 


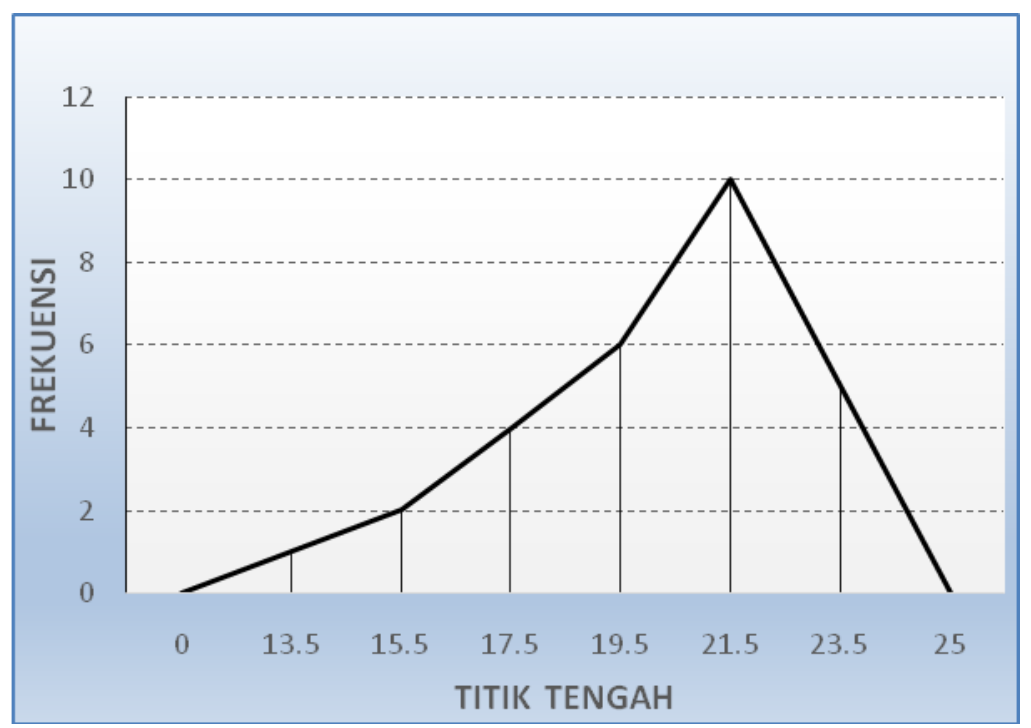

Gambar 1. Kurva Poligon Data Hasil Post-Test Kelompok Eksperimen

Berdasarkan gambar 1, terlihat bahwa sebaran hasil keterampilan menulis kelompok eksperimen merupakan kurva juling negatif, karena hasil yang diperoleh yaitu mean $(M)=$ 20,14 , median $(\mathrm{Me})=20,7$, dan modus $(\mathrm{Mo})=21,3$ yang berarti modus lebih besar dari median dan median lebih besar dari mean (Mo > Me > M). Hal ini menunjukkan bahwa sebagian besar skor siswa cenderung sangat tinggi.

Sementara itu, rata-rata skor keterampilan menulis kelompok kontrol yaitu sebesar 14,80 yang berada pada kategori tinggi. Data kelompok kontrol pada tabel 4 disajikan dalam bentuk kurva poligon pada gambar 2 .

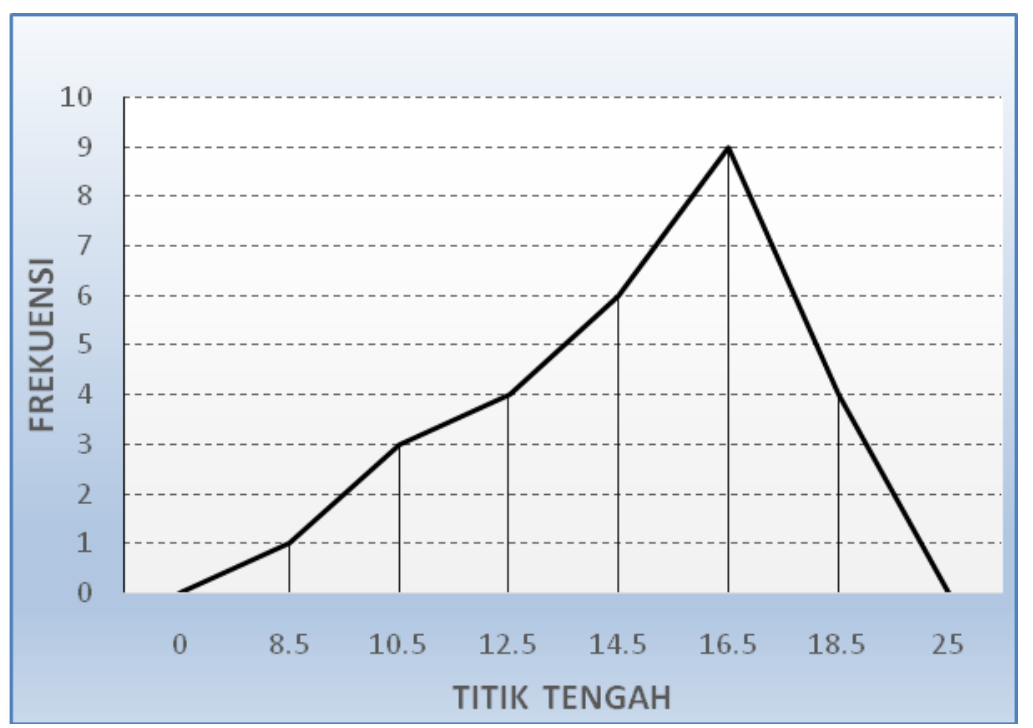

Gambar 2. Kurva Poligon Data Post-Test Kelompok Kontrol

Berdasarkan gambar 2, terlihat bahwa sebaran hasil keterampilan menulis kelompok kontrol merupakan kurva juling negatif, karena hasil yang diperoleh yaitu mean $(M)=14,80$, median $(\mathrm{Me})=15$, dan modus $(\mathrm{Mo})=16,3$ yang berarti modus lebih besar dari median dan median lebih besar dari mean ( $\mathrm{Mo}>\mathrm{Me}>\mathrm{M}$ ). Hal ini menunjukkan bahwa sebagian besar skor siswa cenderung tinggi. 
Sebelum melakukan uji hipotesis, dilakukan uji prasyarat terlebih dahulu yaitu uji normalitas dan uji homogenitas varians. Uji normalitas dilakukan untuk membuktikan kedua sampel tersebut berdistribusi normal dan untuk menyelidiki bahwa $f_{\circ}$ (frekuensi observasi) dari gejala yang diselidiki tidak menyimpang dari fe (frekuensi harapan) dalam distribusi normal empirik. Ringkasan uji normalitas kelompok ekperimen dan kelompok kontrol dapat dilihat pada Tabel 5.

Tabel 5. Ringkasan Hasil Uji Normalitas

\begin{tabular}{lllll}
\hline No. & Sampel Penelitian & $\mathbf{X}^{2}$ hitung & $\begin{array}{l}\text { Nilai Kritis dengan Taraf } \\
\text { Signifikansi 5\% }\end{array}$ & Status \\
\hline 1 & Kelompok eksperimen & 3,48 & 7,815 & Normal \\
2 & Kelompok kontrol & 2,24 & 7,815 & Normal \\
\hline
\end{tabular}

Kriteria pengujian normalitas adalah jika X2hit < X2tab, maka data berdistribusi normal. Sedangkan jika X2hit > X2tab, maka data berdistribusi tidak normal. Dari hasil penghitungan menggunakan rumus Chi-Kuadrat, hasil post-test kelompok eksperimen menunjukkan $\mathrm{X} 2_{\text {hitung }}=3,48$. Berdasarkan tabel distribusi $\mathrm{X} 2$ pada taraf signifikansi $5 \%$ dan $\mathrm{dk}=3$ adalah 7,815. Ini berarti $\mathrm{X} 2_{\text {hitung }}<\mathrm{X} 2_{\text {tabel }}$, maka data hasil post-test kelompok eksperimen berdistribusi normal. Sedangkan pada kelompok kontrol menunjukkan $\chi 2_{\text {hitung }}=$ 2,24. Berdasarkan tabel distribusi $\chi 2$ untuk taraf signifikansi $5 \%$ dan $\mathrm{dk}=3$, nilai $\chi 2$ tabel yaitu 7,815. Ini berarti $\chi 2_{\text {hitung }}<\chi 2_{\text {tabel }}$ maka data hasil post-test keterampilan menulis kelompok kontrol juga berdistribusi normal.

Setelah melakukan uji normalitas, selanjutnya silakukan uji prasyarat yang kedua yaitu uji homogenitas. Uji ini dilakukan terhadap varians pasangan antara kelompok eksperimen dan kelompok kontrol yang dianalisis menggunakan uji $F$ dengan kriteria data homogen jika $F_{\text {hitung }}<F_{\text {tabel. }}$. Rangkuman hasil uji homogenitas varians antara kelompok eksperimen dan kelompok kontrol disajikan pada Tabel 6.

Tabel 6. Rangkuman Hasil Uji Homogenitas Varians

\begin{tabular}{lllll}
\hline Sampel & Varians (S2) & $\mathbf{F}_{\text {hitung }}$ & $\mathbf{F}_{\text {tabel }}$ & Status \\
\hline $\begin{array}{l}\text { Kelompok eksperimen } \\
\text { Kelompok kontrol }\end{array}$ & 7,12 & 1,05 & 1,88 & Homogen \\
\hline
\end{tabular}

Dari hasil pengujian diperoleh $F_{\text {hitung }}=1,05$. Dengan dkpembilang $=27-1=26$, dkpenyebut $=28-1=27$, dan taraf signifikansi $5 \%$ diketahui $F_{\text {tabel }}=1,88$, sehingga Fhit lebih kecil daripada Ftab (Fhit $=1,05<\mathrm{Ftab}=1,88$ ). Hal ini berarti varians kedua kelompok data adalah homogen.

Berdasarkan hasil uji prasyarat analisis diketahui bahwa data keterampilan menulis kelompok eksperimen dan kelompok kontrol berdistribusi normal dan varians homogen. Selanjutnya, dilakukan pengujian hipotesis dengan menggunakan analisis uji-t sampel independent (tidak berkorelasi) dengan rumus polled varians karena $\mathrm{n} 1 \neq \mathrm{n} 2$ dan varians data homogen, dengan derajat kebebasan $(n 1+n 2)-2$, sesuai dengan ketentuan menurut Sugiyono (dalam Koyan, 2012). Hasil uji-t disajikan dalam tabel 7.

Tabel 7. Rangkuman Hasil Uji-t

\begin{tabular}{llcccccc}
\hline No. & Kelompok & $\mathbf{N}$ & $\mathbf{X}$ & $\mathbf{s 2}$ & $\mathbf{t}_{\text {hitung }}$ & $\begin{array}{c}\text { ttabel } \\
\text { (t.s. 5\%) }\end{array}$ & Keterangan \\
\hline 1 & Eksperimen & 28 & 20,14 & 7,12 & 7,32 & 2,006 & H0 ditolak \\
2 & Kontrol & 27 & 14,80 & 7,92 & & & \\
\hline
\end{tabular}


Berdasarkan Tabel 7, diperoleh $t_{\text {hitung }}=7,32$, sedangkan $t_{\text {tabel }}=2,006$ untuk $\mathrm{db}=53$ dengan taraf signifikansi $5 \%$. Hal ini berarti menunjukkan bahwa $t_{\text {hitung }}>t_{\text {tabel }}$, sehingga $\mathrm{HO}$ ditolak dan $\mathrm{H} 1$ diterima.

Berdasarkan kriteria pengujian yaitu $\mathrm{H} 0$ ditolak dan $\mathrm{H} 1$ diterima, hal ini berarti menunjukkan bahwa terdapat pengaruh yang signifikan pendekatan saintifik bermediakan audio visual terhadap keterampilan menulis pada muatan pelajaran bahasa Indonesia siswa kelas IV

SD Gugus XIV Kecamatan Buleleng Kabupaten Buleleng Tahun Pelajaran 2017/2018.Pendekatan saintifik bermediakan audio visual berpengaruh signifikan terhadap keterampilan menulis bahasa Indonesia siswa pada kelompok eksperimen dengan rata-rata yang diperoleh yaitu berada pada kategori sangat tinggi. Hal tersebut dipengaruhi oleh beberapa faktor.

Faktor pertama, dengan diterapkan pendekatan saintifik bermediakan audio visual dapat menarik minat siswa untuk belajar. Penggunaan media audio visual dapat mempermudah guru dalam menyampaikan materi pembelajaran. Siswa lebih tertarik belajar menggunakan media audio visual. Media audio visual memberikan pengalaman yang lebih konkret karena bersifat linier dan variatif, sehingga dapat menarik perhatian siswa dalam proses pembelajaran. Ketertarikan siswa untuk belajar, membuat siswa termotivasi menyampaikan pendapat dan ide-ide dalam menulis. Hal ini sejalan dengan pendapat Wati (2016:45) yang menyatakan "media audio visual merupakan media pembelajaran yang menarik minat belajar siswa karena media ini dapat menampilkan banyak variasi dalam setiap penyajiannya". Hasil penelitian Tariasih (2016) menyatakan pendekatan saintifik berbasis inkuiri terbimbing bermediakan audio visual dapat menarik minat siswa untuk aktif dalam pembelajaran.

Faktor kedua, pembelajaran menggunakan media audio visual membuat suasana pembelajaran di kelas menjadi menyenangkan. Siswa menikmati tayangan yang ditampilkan guru. Siswa lebih senang belajar menggunakan media audio visual. Media audio visual membuat siswa tidak tegang, tidak monoton dan siswa bisa belajar dengan gembira. Kegembiraan yang dirasakan siswa membuat siswa tidak canggung dalam menyampaikan ide atau pendapat. Siswa nyaman berkomunikasi dengan guru dan teman-teman untuk mengembangkan ide atau gagasan yang akan ditulis. Hal ini sejalan dengan penelitian yang dilakukan oleh Giri (2018) yang menyatakan model pembelajaran kooperatif script bermediakan audio visual menciptakan suasana belajar yang menyenangkan, dapat menarik perhatian siswa dan menyebabkan siswa tidak bosan saat pembelajaran.

Faktor ketiga, pembelajaran menggunakan pendekatan saintifik bermediakan audio visual mendorong siswa lebih aktif untuk berpartisipasi dalam pembelajaran. Penggunaan pendekatan saintifik bermediakan audio visual memunculkan rasa ingin tahu yang tinggi dalam diri siswa. Rasa ingin tahu itu membuat siswa berani dan percaya diri untuk aktif mencari apa yang ingin diketahuinya. Keberanian dan percaya diri siswa membuat siswa lebih aktif dalam mengemukakan pendapat dan ide-ide dalam menulis. Selain itu, pendekatan saintifik memberikan kesempatan kepada siswa untuk melatih kemampuan berkomunikasi dan menyampaikan ide atau pendapat sehingga siswa menjadi aktif berpartisipasi dalam proses pembelajaran. Hal ini sejalan dengan pendapat Kurniasih dan Sani (2014:33) yang menyatakan "tujuan pembelajaran menggunakan pendekatan saintifik yaitu melatih siswa dalam mengomunikasikan ide-ide, khususnya dalam menulis". Hasil penelitian Dewi (2015) menunjukkan bahwa pembelajaran menggunakan pendekatan saintifik berbasis lingkungan memberikan kesempatan kepada siswa untuk berlatih dalam mengomunikasikan ide-ide, khususnya dalam menulis.

\section{Simpulan dan Saran}

Berdasarkan hasil analisis menggunakan uji-t menunjukkan bahwa $t_{\text {hitung }}=7,32$ dan $t_{\text {tabel }}=2,006$. Hal ini berarti nilai $t_{\text {hitung }}>t_{\text {tabel }}$, sehingga terdapat perbedaan yang signifikan pendekatan saintifik bermediakan audio visual terhadap keterampilan menulis pada muatan 
pelajaran bahasa Indonesia. Kualifikasi hasil konversi ke dalam PAP skala lima, rata-rata keterampilan menulis bahasa Indonesia siswa yang belajar menggunakan pendekatan saintifik bermediakan audio visual berada pada kategori sangat tinggi. Sedangkan rata-rata keterampilan menulis bahasa Indonesia siswa yang belajar tidak menggunakan media audio visual berada pada kategori tinggi. Dengan demikian, dapat disimpulkan bahwa pembelajaran menggunakan pendekatan saintifik bermediakan audio visual berpengaruh signifikan terhadap keterampilan menulis bahasa Indonesia kelas IV SD Gugus XIV Kecamatan Buleleng tahun pelajaran 2017/2018.

Berdasarkan temuan-temuan dalam penelitian ini, dapat disampaikan saran-saran sebagai berikut. a) Siswa dalam mengikuti proses pembelajaran hendaknya selalu terlibat secara aktif agar nantinya dapat meningkatkan keterampilan menulis dan mendapatkan pengetahuan baru melalui pengalaman yang ditemukannya sendiri, b) Guru dalam menyampaikan materi pelajaran keterampilan menulis hendaknya menggunakan pendekatan saintifik bermediakan audio visual yang mana nantinya mampu mengatasi kebutuhan belajar dan karakteristik siswa, c) Kepada kepala sekolah, khususnya sekolah dasar hendaknya dapat menjadikan media audio visual sebagai salah satu media pembelajaran yang harus diterapkan dalam pembelajaran, pada aturan guru mengajar di kelas, dan d) Peneliti lain yang akan mengadakan penelitian lebih lanjut tentang pendekatan saintifik bermediakan audio visual pada aspek yang berbeda dalam bidang pelajaran bahasa Indonesia maupun pelajaran lainnya yang sesuai agar memperhatikan kendala-kendala yang dialami dalam penelitian ini sebagai bahan pertimbangan untuk perbaikan dan penyempurnaan penelitian yang akan dilaksanakan.

\section{Daftar Rujukan}

Dewi, Kadek Ayu Sasmita, dkk. 2015. Pengaruh Pendekatan Saintifik Berbasis Lingkungan Terhadap Keterampilan Menulis Siswa Kelas IV. E-journal. Mimbar PGSD. Universitas Pendidikan Ganesha. Vol. 3, No. 1:2, 7-9.

Djamarah, Syaiful Bahri dan Aswan Zain. 2006. Strategi Belajar Mengajar. Jakarta: PT Rineka Cipta.

Giri, Kadek Yondika Yusa. 2018. Pengaruh Model Pembelajaran Kooperatif Script Bermediakan Audio Visual Terhadap Hasil Belajar IPS Kelas IV. E-journal. Mimbar PGSD. Universitas Pendidikan Ganesha. Vol. 6, No. 1.

Hasan, Hasmiana. 2016. Penggunaan Media Audio Visual terhadap Ketuntasanbelajar IPS Materi Perkembangan Teknologi Produksi, Komunikasi, dan Transportasi pada Siswa Kelas IV SD Negeri 20 Banda Aceh. Jurnal Pesona Dasar Vol. 3 No.4 Hal. 22-33. Tersedia Pada : http://www.jurnal.unsyiah.ac.id/PEAR/article/view/7538.

Koyan, I Wayan. 2012. Statistika Pendidikan Teknik Analisis Data Kuantitatif. Singaraja: Universitas Pendidikan Ganesha Press.

Kurniasih, Imas dan Berlin Sani. 2014. Sukses Mengimplementasikan Kurikulum 2013. Jakarta: Kata Pena.

Musfiqon dan Nurdyansyah. 2015. "Pendekatan Pembelajaran Saintifik". Sidoarjo: Nizamia Learning Center.

Sayidiman. 2012. Penggunaan Media Audio Visual dalam Merangsang Minat Mahasiswa terhadap Mata Kuliah Seni Tari. Jurnal Publikasi Pendidikan, Volume II No. 1 Hal. 3643. Tersedia Pada : http://ojs.unm.ac.id/pubpend/article/download/1583/645. 
Sumantri, Made, dkk. 2014. Peningkatan Keterampilan Berbahasa Indonesia. Singaraja: Universitas Pendidikan Ganesha.

Supriatini. 2017. Penerapan Media Audio Visual dalam Meningkatkan Keterampilan Menulis Puisi Siswa Kelas VIII SMP Negeri 13 Palembang. Jurnal Bindo Sastra Vol. 1 No.1 Hal. 45-51. Tersedia Pada : http://jurnal.um-palembang.ac.id/bisastra/article/view/667.

Susanto, Ahmad. 2013. Teori Belajar dan Pembelajaran di Sekolah Dasar. Jakarta: Kencana Prenadamedia Group.

Tariasih, dkk. 2016. Pengaruh Pendekatan Saintifik Berbasis Inkuiri Terbimbing Bermediakan Audio-Visual Berpengaruh terhadap Hasil Belajar IPS. E-journal. Mimbar PGSD. Universitas Pendidikan Ganesha. Vol. 4, No. 1:7.

Tegeh, I Made. 2010. Media Pembelajaran. Singaraja: Universitas Pendidikan Ganesha.

Wati, Ega Rima. 2016. Ragam Media Pembelajaran. Jakarta: Kata Pena.

Wicaksono, Andi. 2017. Peran Media Audio dalam Meningkatkan Kualitas Proses Pembelajaran Apresiasi Cerita Pendek. SHAHIH - Vol. 2 No. 1 Hal. 67-78. Tersedia Pada : https://ejournal.iainsurakarta.ac.id/index.php/shahih/article/view/670.

Yunus, Mohamad. 2014. Pendidikan Bahasa Indonesia di SD.Tangerang Selatan: Universitas Terbuka. 